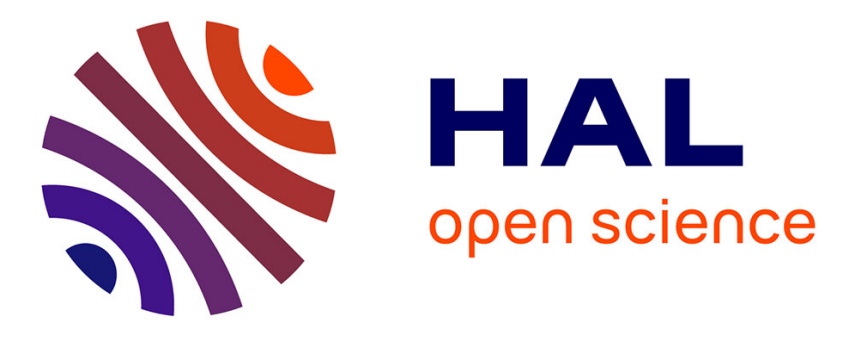

\title{
Role of the nicotinic acetylcholine receptor in Alzheimer's disease pathology and treatment.
}

Sylvia Lombardo, Uwe Maskos

\section{To cite this version:}

Sylvia Lombardo, Uwe Maskos. Role of the nicotinic acetylcholine receptor in Alzheimer's disease pathology and treatment.. Neuropharmacology, 2015, The Nicotinic Acetylcholine Receptor: From Molecular Biology to Cognition, 96 (Pt B), pp.255-62. 10.1016/j.neuropharm.2014.11.018 . pasteur01197130

\section{HAL Id: pasteur-01197130}

\section{https://hal-pasteur.archives-ouvertes.fr/pasteur-01197130}

Submitted on 11 Sep 2015

HAL is a multi-disciplinary open access archive for the deposit and dissemination of scientific research documents, whether they are published or not. The documents may come from teaching and research institutions in France or abroad, or from public or private research centers.
L'archive ouverte pluridisciplinaire HAL, est destinée au dépôt et à la diffusion de documents scientifiques de niveau recherche, publiés ou non, émanant des établissements d'enseignement et de recherche français ou étrangers, des laboratoires publics ou privés.

\section{(ㅇ)(1) $\$$}

Distributed under a Creative Commons Attribution - NonCommercial - NoDerivatives 44.0 


\section{Corresponding author: sylvia.lombardo@pasteur.fr}

Abbreviations: Acetylcholine (ACh), Acetylcholinesterase (AChE), Alzheimer's Disease (AD), Amyloid ß peptide (Aß), Amyloid precursor protein (APP), Choline Acetyltransferase (ChAT), desformylflustrabromine (dFBr), familial AD (fAD), Filamin A (FLNA), Knock-out (KO), Methyllycaconitine (MLA), muscarinic acetylcholine receptors (mAChRs), nicotinic acetylcholine receptors (nAChRs), Pregnenolone sulfate (PREGS), positive allosteric modulator (PAM), prefrontal cortex (PFC), Simvastatin (SV).

\section{Introduction}

Dementia is a debilitating condition frequent in ageing populations, and Alzheimer's Disease (AD) accounts for $70 \%$ of all dementia cases. $\mathrm{AD}$ is characterized by neuropathological hallmarks consisting of an accumulation of Amyloid $\beta$ peptide $(A ß)$ in extracellular plaques, intracellular deposits of tau protein, neuronal loss and, more recently, a prominent synaptic loss was identified (Braak and Braak, 1991; Masliah et al., 2001; Selkoe, 1991; Spires-Jones and Hyman, 2014). In addition, anatomical studies in AD patients showed a massive loss of brain white matter and a specific reduction of cholinergic neurons of the basal forebrain (Auld et al., 2002; Bowen et al., 1976; Coyle et al., 1983; Kim et al., 2013; Whitehouse et al., 1981, 1982). Cholinergic neurons are organized in dense nuclei with widespread projections that entirely cover the central nervous system. In particular, the cholinergic neurons, whose cell bodies are in the basal forebrain, send their long projections to the neocortex and hippocampus (Bigl et al., 1982; Mesulam et al., 1983). Several studies demonstrated the pivotal role of these cholinergic nuclei in cognitive functions. Woolf (1998) proposed a model in which acetylcholine $(\mathrm{ACh})$ release leads to the modulation of cortical circuitry that finally encodes for storage of long-term memory. The cholinergic system is also involved in attention 
processes (Muir et al., 1993; Sarter and Bruno, 1997; Wenk, 1997). In a mouse model, the lack of ACh receptors in the prefrontal cortex (PFC) was demonstrated to be responsible for attention deficit, restored by the expression of the receptor in this area (Guillem et al., 2011). The neurotransmitter ACh binds to two families of receptors, nicotinic acetylcholine receptors (nAChRs) and muscarinic acetylcholine receptors (mAChRs). Both families of receptors regulate the cognitive processes mentioned above (Ghoneim and Mewaldt, 1977; Petersen, 1977; Sarter and Paolone, 2011), and are both affected in AD.

Binding studies performed with the use of $[3 \mathrm{H}]$-nicotine and $[3 \mathrm{H}]-\mathrm{ACh}$ showed a significant reduction in nicotine and $\mathrm{ACh}$ binding sites in cerebral cortex of patients suffering from $\mathrm{AD}$, demonstrating a decrease of both nAChR and mAChR populations (Gotti et al., 2006a; Paterson and Nordberg, 2000; Perry et al., 1981, 1985, 1987, 1988; Shimohama et al., 1986; Whitehouse et al., 1981, 1982, 1986). In addition to nAChRs and mAChRs, the enzyme choline acetyltransferase (ChAT), involved in ACh production, is also affected in AD. The activity of this ChAT enzyme, and consequently the synthesis of ACh, is decreased in AD brains. In addition, several authors observed a reduction in the activity of acetylcholinesterase (AChE), the enzyme that metabolises ACh after its release in the synaptic cleft (Auld et al., 2002; Bowen et al., 1976; Coyle et al., 1983; Davies and Maloney, 1976; Perry et al., 1978). The role of the cholinergic system in cognition and the modification observed in neurodegenerative diseases, and in particular in the case of $\mathrm{AD}$, led to the formulation of the “cholinergic hypothesis" of geriatric disorders (Bartus et al., 1982; Contestabile, 2011), according to which the reduction in cholinergic innervation is responsible for the cognitive decline observed in $\mathrm{AD}$ patients.

In this context, we will focus on $\mathrm{nAChRs}$, since their involvement in $\mathrm{AD}$ has been largely demonstrated, while the contribution of mAChRs has been under-explored. The purpose of this review is to present evidence implicating the role of nAChRs in $\mathrm{AD}$, discuss the data 
supporting their interaction with $A \beta$, and the consequences of the perturbation of this interaction in murine models.

\section{Brief overview of $\mathrm{nAChR}$ subtypes involved in AD}

Nicotinic receptors are transmembrane pentameric proteins that belong to the "cys-loop" superfamily of ligand-gated ion channels together with GABAA, GABAC, glycine and 5hydroxytryptamine (5-HT3) ionotropic receptors (Changeux and Edelstein, 1998; Le Novère and Changeux, 1995). They are composed of a variety of $\alpha$ and $\beta$ subunits, which determine the pharmacological and kinetic properties of the receptor (Albuquerque et al., 2009; Giniatullin et al., 2005). The five subunits that compose the receptor are assembled around a central hydrophilic pore that mediates the flow of the cations $\mathrm{K}^{+}, \mathrm{Na}^{+}$and $\mathrm{Ca}^{++}$. In the human nervous system, there are eight $\alpha$ subunits $(\alpha 2-\alpha 7, \alpha 9, \alpha 10)$ and three $\beta$ subunits ( $\beta 2-\beta 4)$ that assemble in different combinations to generate a variety of nAChR subtypes with distinct electrophysiological properties and brain localization (Albuquerque et al., 2009; Gotti et al., 2006b, 2007, 2009).

The use of radioactive ligands allowed nAChR classification into two distinct groups, $\alpha$ Bungarotoxin sensitive and $\alpha$ Bungarotoxin insensitive receptors (Gotti and Clementi, 2004). Homopentameric $\alpha 7$ nAChRs belong to the first class, while heteropentameric nAChRs containing the 32 subunit belong to the second class. In this context we will focus on these $\alpha 7$ and $\beta 2$ subunits, that were shown to interact with Aß (Liu et al., 2009, 2012; Søderman et al., 2008; Sudweeks and Yakel, 2000; Wang et al., 2000a, 2000b).

The $\alpha 7$ homomeric receptor demonstrates a wide-spread localization in the brain and is characterized by a high calcium ion permeability and a fast desensitization rate (Dani and Bertrand, 2007; Quick and Lester, 2002). $\alpha 7 \mathrm{nAChR}$ on presynaptic terminals mediate release of others neurotransmitters (Wonnacott et al., 2006), while a postsynaptic or somatic 
localization elicits important changes in intracellular $\mathrm{Ca}^{++}$concentration, that can activate second messenger pathways mediating cellular processes such as neuronal survival and gene expression (Berg and Conroy, 2002; Messi et al., 1997; Morley and Happe, 2000). Moreover, it was demonstrated that the activation of $\alpha 7 \mathrm{nAChRs}$ is important during development for the maturation of glutamatergic synapses (Lozada et al., 2012).

The role of $\alpha 7$ in memory and attention has been investigated for a long time. Knock-out (KO) mice for this subunit did not show a clear cognitive or attention deficit, except when the behavioural paradigm used implied prolonged sessions (Young et al., 2004, 2007). Historically, the first nAChR subunit identified to interact with $A \beta$ was $\alpha 7$ (Wang et al., 2000a, 2000b). Later it was shown that $A ß$ is able to activate also $\beta 2 *$-nAChRs ( $\beta 2$ subunitcontaining nAChRs). This subunit commonly forms heteropentameric receptors in combination with the $\alpha 4$ subunit. The pharmacological and functional characteristics of these heteromeric receptors are determined by both the contributing $\alpha$ and $\beta$ subunits. The subtype $\alpha 4 \beta 2$ is characterized by lower calcium ion permeability and a slow desensitization rate compared to the homopentameric $\alpha 7$ nAChR (Quick and Lester, 2002). The "classic" highaffinity nAChR is composed of $\alpha 4$ and $\beta 2$ subunits (Zoli et al., 1998). In addition to the $\alpha 4 \beta 2$ subtype, it was demonstrated that the $\alpha 7$ subunit is able to co-assemble with the $\beta 2$ subunit to form a heteropentameric receptor. This novel $\alpha 7 ß 2$ subtype was first investigated by expressing the heteromer in Xenopus oocytes. Recently, the $\alpha 7 ß 2 *$ nAChR subtype was found in basal forebrain cholinergic neurons and hippocampal interneurons of mouse brain, and in the human basal forebrain (Moretti et al., 2014). This class of receptors seems to be particularly sensitive to Aß-induced toxicity (Khiroug et al., 2002; Liu et al., 2009, 2012). The existence of this novel subtype was further confirmed in a human cell line (SHEP-1) transfected with the cDNA for $\alpha 7$ and $\beta 2$ subunits. Under these experimental conditions, $\alpha 7$ and 32 are able to co-assemble into a functional receptor that localizes at the cell surface. The 
ability of $\alpha 7$ and $\beta 2$ subunits to form a functional receptor was confirmed in $X$. laevis oocytes. This heteromer displayed only a modest difference in the electrophysiological response to pharmacological agents compared to the homomeric $\alpha 7$ nAChR (Murray et al., 2012). The exact stoichiometry of this recently discovered subtype was not defined. It is clear that functional ligand binding domains could only be formed at the $\alpha 7-\alpha 7$ interface. Murray et al. (2012) proposed a schematic model of all the possible stoichiometries for the $\alpha 7 ß 2$ subtype.

The importance of $\beta 2$ in maintaining brain homeostasis during normal ageing was highlighted in the KO mouse for this subunit. Aged 32 null mutant mice have a thinner cortex compared to age-matched wild-type controls (Zoli et al., 1999). This work should be pursued further as it indicates a "neurotrophic" action of $\beta 2$ receptor activation by endogenous ACh (Zanardi et al., 2007). Null mutant $\beta 2$ mice were also tested to determine the role of this subunit in cognition. Guillem et al. (2011) showed that these mice exhibit an attention deficit which was restored by re-expression of this subunit with a lentiviral vector in the PFC.

We will now present and discuss the data demonstrating the existence of a physical interaction between $\mathrm{nAChR}$ and $\mathrm{A} \beta$, the functional consequences of this interaction and the intracellular pathways activated.

\section{Interaction between $\mathrm{nAChRs}$ and $\mathrm{AB}$}

The interaction between the $\alpha 7 \mathrm{nAChR}$ and $\mathrm{A} \beta$ is widely demonstrated. The first indication of this interaction came from the experiments of Wang et al. (2000a, 2000b). They showed that $\alpha 7$ subunits co-localize with $A \beta_{1-42}$ in senile plaques of brain slices obtained from patients that suffered from sporadic $\mathrm{AD}$. In this context, no co-localization was found between $\mathrm{A} B$ and the $\alpha 4$ subunit. The strong and specific association between $A ß$ and $\alpha 7$, and no other subunits of the nAChRs, was further demonstrated with immunoprecipitation and Western Blot analysis. This set of experiments showed that $A \beta_{1-42}$ is able to immunoprecipitate $\alpha 7$, which was not the 
case for other $\mathrm{nAChR}$ subunits such as $\alpha 1, \alpha 3, \alpha 4, \alpha 8$ or $\beta 2$. The same result was obtained with the reciprocal experiment, $\alpha 7$ immunoprecipitation and $A \beta_{1-42}$ detection, meaning that the two proteins strongly interact. Experiments performed with fragments of $A ß$ helped identify the sequence responsible for the interaction with $\alpha 7$, which corresponds to the amino acid residues $12-28$ of the $A ß$ sequence (Wang et al., 2000b). Subsequently, competition studies performed by incubating $\alpha 7$ nAChRs with $A B$ and $\alpha$ Bungarotoxin showed that the application of $\alpha$ Bungarotoxin is able to decrease the amount of $A \beta$ bound to $\alpha 7 \mathrm{nAChRs}$, suggesting that both molecules compete for the same ligand binding domain (Wang et al., 2000b). Furthermore, studies using two selective nicotinic receptor ligands, namely $[3 \mathrm{H}]$ methyllycaconitine and [3H]cytisine, clearly showed that $\alpha 7 \mathrm{nAChRs}$ bind the less toxic peptide $A \beta_{1-40}$, but with lower affinity compared to the 1-42 form (Wang et al., 2000a). Direct interaction between $A \beta$ and $\alpha 7$ was further demonstrated in a transgenic mouse line, APPSwe/PS1 $\Delta \mathrm{E} 9$, where $\alpha 7$ was shown to immunoprecipitate with $\mathrm{A} \beta_{1-40 / 42}$ (Søderman et al., 2008). Modulation of $\mathrm{nAChRs}$ by $\mathrm{A} ß$ was also found in ex vivo studies: Pettit and colleagues (2001) used rat hippocampal slices to show that $A \beta_{1-42}$ incubation is able to reduce postsynaptic currents and open probability of both $\alpha 7$ and non- $\alpha 7$ nAChRs subtypes, demonstrating an interaction between $A \beta$ and other $n A C h R$ subunits. Even though studies have mainly focused on the interaction between $\alpha 7 \mathrm{nAChRs}$ and $\mathrm{A} \beta$ and its functional consequences, it has been demonstrated that also $B 2 *-n A C h R s$ bind to $A ß$. The evidence supporting this interaction comes mostly from electrophysiological studies (Lamb et al., 2005; Liu et al., 2009, 2012; Wu et al., 2004).

Several papers from the Yakel laboratory (Lamb et al., 2005; Pandya and Yakel, 2011; Pettit et al., 2001) have investigated the action of $A B$ on these heteromeric receptors. In both hippocampal interneurons and oocytes they observed a block of $\beta 2 *$-nAChRs, that could be prevented by the application of a positive allosteric modulator (PAM) specific for 32 subunit 
containing receptors, desformylflustrabromine (dFBr) (Pandya and Yakel, 2011). These are the only conclusive studies to our knowledge, and it will probably be important to continue this dissection.

\section{Functional consequences of $\mathrm{nAChR}-\mathrm{AB}$ interaction}

In this paragraph we will summarize the extensive literature that covers $\mathrm{nAChR}$ functional activation or inhibition mediated by $A \beta$, with emphasis on $n A C h R$ subtype, $A ß$ concentration and experimental model used. The literature presents conflicting results about functional consequences of $\mathrm{A} \beta$ binding on $\mathrm{nAChRs,} \mathrm{eliciting} \mathrm{in} \mathrm{some} \mathrm{studies} \mathrm{a} \mathrm{receptor} \mathrm{activation,} \mathrm{and}$ in others an inhibition (Pettit et al., 2001; Puzzo et al., 2008; Tozaki et al., 2002). In order to be able to compare and interpret these contrasting observations, we should be aware of the variability stemming from the different approaches used, such as the difference in receptor subtype (homo- or hetero-pentameric receptors), the system used for electrophysiological recordings (Xenopus oocytes that express transiently the subunits versus organotypic slices and cellular systems), and most importantly, the $A B$ preparation used (concentration and aggregation status). For instance, there is variability in the characteristics and toxicity of the oligomeric vs fibrillar species of Aß (Selkoe, 2011; Walsh and Selkoe, 2004). Below, we will summarize the most remarkable findings over the past years.

Important evidence for a functional interaction between $\mathrm{nAChRs}$ and $\mathrm{A} ß$ came from the work of Pettit et al (2001). They demonstrated that $A \beta_{1-42}$ drives a reversible inhibition of $n A C h R-$ mediated currents in hippocampal GABAergic neurons recorded from rat slices. In these experimental conditions the most effective $A \beta_{1-42}$ concentration was $500 \mathrm{nM}$, but inhibition was found also at the lower concentration of $100 \mathrm{nM}$. With the use of selective antagonists it was possible to determine that inhibition operates on both $\alpha 7$ and non- $\alpha 7$ receptors (Pettit et al., 2001). Experiments performed on Xenopus laevis oocytes transiently transfected with $\alpha 7$ 
or $\alpha 4 \beta 2$ cDNA showed a concentration dependent effect of $A ß$ on receptor inhibition. In this case the peptide used was $A \beta_{1-40}$ and the concentrations adopted were between 0.1 and $10 \mu \mathrm{M}$, with increased $A ß$ concentration resulting in a bigger inhibition of the receptor (Tozaki et al., 2002). A different set of experiments demonstrated that $A B$ enhances $A C h$ activation of the $\alpha 4 \beta 2 \mathrm{nAChRs}$ expressed in oocytes, this first activation of the receptor was followed by its inhibition (Pym et al., 2005). However, $\alpha 7$ nAChR activation was observed in $X$. laevis oocytes when a range of $A ß$ concentration spanning from 1 to $100 \mathrm{pM}$ was applied (Dineley et al., 2002). Using a different experimental model, Liu et al. (2001) obtained a different outcome. The incubation of cultured rat hippocampal neurons with $A \beta_{1-42}$ resulted in inhibition of $\alpha 7$ nAChRs, more precisely of both somato-dendritic and presynaptic populations of receptors. In this case, non- $\alpha 7 \mathrm{nAChRs}$ were insensitive to $A ß$ inhibition (Liu et al., 2001). Further studies showed an inhibitory effect of $A \beta_{1-42}$ on human $\alpha 4 \beta 2$ nAChRs trasnfected in the cell line (SHEP1) (Wu et al., 2004). Other work performed in cellular systems on human nAChRs showed receptor activation. The oligomeric form of $A \beta_{1-40}$ was able to activate $\alpha 7$ nAChR expressed in SH-SY5Y cell line (Lilja et al., 2011). Arora et al. (2013) investigated, in a cellular system, the effect of prolonged Aß exposure on nAChR function. The rodent neuroblastoma cell line NG108-15 was transfected with $\alpha 4 \beta 2$ nAChRs and treated for three days with $100 \mathrm{nM} \mathrm{Aß}$. The following acute stimulation with $\mathrm{A} B$ and nicotine led to receptor activation that caused a perturbation of intracellular calcium homeostasis followed by mitochondrial dysfunction and increased oxidative stress (Arora et al., 2013). In a different study, rat hippocampus and cortex were investigated and the activation of both $\alpha 7$ and non- $\alpha 7$ receptors was obtained with an enhancement of $\mathrm{Ca}^{++}$influx into the neuron following the application of picomolar $(\mathrm{pM})$ concentrations of $A \beta_{1-42}$. In this case, a distinct response of homomeric and heteromeric receptors was found, specifically, $\alpha 7$ are activated at $\mathrm{pM}$ concentrations of $\mathrm{A} \beta$, while non- $\alpha 7$ receptors were responsive at $\mathrm{nM} A \beta$ 
concentrations (Dougherty et al., 2003). A study performed on nerve endings with application of $A ß$ demonstrated a non competitive action of $A \beta_{1-40}$ on $\alpha 4 \beta 2$ nAChR (Olivero et al., 2014). In conclusion, the outcome of receptor activation or inhibition depends on the system used and on $A B$ concentration. In general, it is possible to summarize that short incubation and lower concentration lead to receptor activation (Dineley et al., 2002; Dougherty et al., 2003; Puzzo et al., 2008), while longer incubation period and higher peptide concentrations give rise to an inhibitory effect (Dineley et al., 2001; Parri et al., 2011; Pettit et al., 2001). However, due to the variability in the experimental models used, the concentration and aggregation form of $\mathrm{A} ß$ (see Table 1), and in the obtained data, it is not possible to definitively conclude whether $\mathrm{A} ß$ binding on $\mathrm{nAChRs}$ exerts an inhibitory or excitatory effect in a physiological context.

However, it is clear that $\mathrm{nAChR}-\mathrm{A} \beta$ interaction initiates intracellular signalling implicating a set of transduction cascades. Akt phosphorylation mediates the downstream activation of an anti-apoptotic pathway, which is also activated by nicotine treatment (Kihara et al., 2001). The molecular pathways activated are associated with neuroprotection, synaptic plasticity, learning and memory (Plant et al., 2003; Puzzo et al., 2008). Subsequent to incubation with pM concentrations of $A \beta_{1-42}$ monomers and oligomers, an increase of hippocampal LTP was observed. This enhancement of synaptic plasticity and the activation of intracellular pathways are mediated by the activation of $\alpha 7$ nAChRs (Dineley et al., 2001; Parri et al., 2011; Plant et al., 2003; Puzzo et al., 2008). An in vivo $A ß$ infusion in mice was able to enhance hippocampal dependent memory, highlighted with memory tasks such as the Morris water maze and contextual fear conditioning, which are both hippocampus dependent behavioural tasks (Puzzo et al., 2008). On the other hand, an opposite effect was shown with Aß-nAChR interaction being responsible for inhibition of survival pathways. In this system enhancement of Akt phosphorylation and activation of ERK pathway was observed following $\alpha 7$ agonist 
treatment, suggesting that $A ß$ inhibits the neuroprotective effect of $\alpha 7 \mathrm{nAChR}$ activation (Zhi et al., 2014). Even though some key differences in $A ß$ concentration used among the different studies are present, it is possible to conclude that in certain conditions $A ß$ activates survival pathways. It was then postulated that $A B-n A C h R$ interaction has a physiological role in neuronal homeostasis that is disrupted when $A ß$ concentrations increase in a pathological context, leading to receptor inhibition and possible cellular toxicity (Dineley et al., 2001; Parri et al., 2011).

\section{5. nAChR null-mutants in AD}

An interesting approach to study the role of $\mathrm{nAChRs}$ in $\mathrm{AD}$ in vivo is to generate $\mathrm{KO}$ transgenic mice for $\mathrm{nAChRs}$ subunits expressing fAD (familial AD) associated mutations. This method was used to investigate the role of the $\alpha 7$ subunit in $\mathrm{AD}$, a strategy that has so far not been used for the other nAChR subunits. Two examples from the literature showed strikingly opposite outcomes (Dziewczapolski et al., 2009; Hernandez et al., 2010). In the first study conducted by Dziewczapolski et al. (2009), a mouse model, that we will refer to as APP- $\alpha 7 \mathrm{KO}$, was generated by crossing an AD model that expresses the human APP (Amyloid precursor protein) with the Swedish (KM670/671NL) and the Indiana (V717F) mutations (Mucke et al., 2000), with the $\alpha 7$ nAChR null-mutant (Orr-Urtreger et al., 1997). This AD model displays spatial memory deficit at 13-16 months of age, while APP- $\alpha 7 \mathrm{KO}$ mice did not exhibit any memory deficit, suggesting that the absence of the $\alpha 7$ subunit of the nicotinic receptor protects against the behavioural deficit caused by expression of the mutated forms of $\mathrm{APP}$ in this $\mathrm{AD}$ model. It is known that $\mathrm{AD}$ mice display some pathological modifications, like loss of synaptic and dendritic markers, such as synaptophysin and MAP2 (Games et al., 1995; Hsia et al., 1999). In the APP- $\alpha 7 \mathrm{KO}$ line the lack of $\alpha 7$ was sufficient to preserve synaptic terminals and dendrites, rescuing levels of synaptophysin and MAP2 to 
reach that of aged-matched WT controls. To investigate whether the difference in APP expression in the different mouse lines was responsible of the lack of neuropathology, Western Blot and ELISA analyses were performed. These experiments confirmed that the level of expression of APP and the consequent synthesis of $A ß$ were comparable between mouse lines, demonstrating that the difference in cognitive deficit and neuropathology were mediated exclusively by the nicotinic receptor. In addition, APP mice demonstrated a deficit in LTP while APP- $\alpha 7 \mathrm{KO}$ mice did not display this phenotype. The authors postulated that the absence of $\alpha 7$ could prevent $A \beta$ intracellular accumulation ameliorating the cognitive neuropathology and its phenotypic association (Dziewczapolski et al., 2009).

A second study was published by Hernandez et al. (2010). In their work, the transgenic AD model line Tg2576 expressing the human APP sequence with the Swedish mutation (Hsiao et al., 1996) was crossed with the $\alpha 7 \mathrm{KO}$ mouse (Orr-Urtreger et al., 1997) to establish a different APP- $\alpha 7 \mathrm{KO}$ line. In this series of experiments the mice were tested with a panel of behavioural tasks at five months of age, investigating the role of $\alpha 7$ in early AD. The contextual fear conditioning and the novel object recognition tasks both showed that the cognitive deficits worsen when $\alpha 7$ is absent. In the hippocampus, it was shown that APP$\alpha 7 \mathrm{KO}$ mice had high levels of Aß, although significantly less than APP mice, an effect which is not due to modification of the APP expression level, equivalent in the two lines. As a consequence of the lower Aß concentration, the plaque load was clearly reduced in APP$\alpha 7 \mathrm{KO}$ mice. Signs of neuropathology were found in APP- $\alpha 7 \mathrm{KO}$ illustrated by loss of MAP2 immunoreactivity in the hippocampus. In conclusion, this study demonstrated the protective role of $\alpha 7 \mathrm{nAChRs}$. The mechanism proposed is that the $\mathrm{A} \beta-\alpha 7 \mathrm{nAChR}$ interaction could activate neuroprotective downstream pathways (Parri et al., 2011), and that at the same time the interaction engages $A ß$ preventing its aggregation. With the progression of the disease the amount of $A \beta$ increases, it starts to accumulate, and becomes toxic for the neurons 
(Hernandez et al., 2010).

In conclusion, $\alpha 7 \mathrm{nAChRs}$ seem to have a dual effect depending on the age of the mice tested and probably on $\mathrm{A} \beta$ concentration and aggregation state. However, the $\mathrm{AD}$ model used to generate the APP- $\alpha 7 \mathrm{KO}$ line express different fAD associated mutations (Swedish and Indiana mutations in Dziewczapolski et al., 2009; Swedish mutation in Hernandez et al., 2010). The different mutations cause AD pathology to develop in distinct ways, making it difficult to directly compare the results (see Table 2).

\section{Pharmacological interference between $\alpha 7$ nAChR-Aß binding}

A possible therapeutic approach for $\mathrm{AD}$ treatment is the use of $\mathrm{nAChR}$ agonists or antagonists to interfere with nAChR-Aß interaction. Numerous molecules with agonist or antagonist activity on nAChRs exist. The protective role of these molecules against $A ß$ toxicity was widely demonstrated using many experimental models and approaches. Gao et al. (2014) investigated the neuroprotective effect of cotinine, nicotine and their analogs, in vitro on primary cultures of rat cortical and hippocampal neurons. Cotinine is a nicotine metabolite known for its positive effects on memory and attention and lower toxicity compared to nicotine (Hatsukami et al., 1997). Methyllycaconitine (MLA), an $\alpha 7 \mathrm{nAChR}$ antagonist, showed neuroprotective effect on mouse and rat primary cell culture (Martin et al., 2004). Another molecule investigated was 2-[2-(4- bromophenyl)-2-oxoethyl]-1-methyl pyridinium (S 24795), a partial $\alpha 7 \mathrm{nAChR}$ agonist. When this molecule was applied to synaptosomal preparations from rat frontal cortex and post mortem human $\mathrm{AD}$ samples it was able to dissociate $A ß$ in a concentration dependent manner. The incubation with $\mathrm{S} 24795$ was able to normalize $\mathrm{Ca}^{++}$influx mediated by both $\alpha 7$ nAChR and NMDAR (Wang et al., 2009, 2010). Many other examples of neuroprotective effects elicited by nAChR agonists exist in the literature. However, here we will focus on the results obtained with in vivo experimentation. 
The first attempt to treat an AD mouse model with nicotine was performed by Nordberg et al. (2002). The transgenic line harbouring Swedish double mutations (Hsiao et al., 1996) was treated for 5.5 months with nicotine in the drinking water. $\mathrm{APP}_{\text {Swe }}$ mice showed a reduction in plaque load of $80 \%$ compared to sucrose treated mice. The analysis of the $A ß$ fraction reduced by nicotine showed that mainly insoluble $A \beta_{1-40 / 42}$ was affected while there was no change in soluble Aß (Nordberg et al., 2002). Another study investigated the effect of short and longterm nicotine treatment in the same $\mathrm{APP}_{\text {Swe }}$ line. Nicotine was administered through subcutaneous injections for 10 consecutive days on 9 month old transgenic mice. For longterm administration, mice were treated with nicotine in the drinking water for a period of 5.5 months. The short-term treatment of 10 days showed a significant reduction in cortical insoluble $A \beta_{1-40 / 42}$. Long-term nicotine administration elicited a reduction in $A ß$ deposits in

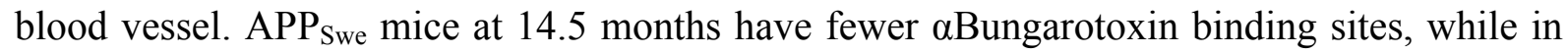
transgenic mice treated with nicotine the number of $\alpha$ Bungarotoxin binding sites was recovered and comparable to non transgenic age-matched control mice, suggesting that there was an increase in the population of $\alpha 7$ nAChRs (Hellström-Lindahl et al., 2004). Inestrosa et al. (2013) then investigated the effect of intraperitoneal nicotine injections in the APP/PS1 double transgenic line. This line expresses fAD associated mutations in both APP and Presenilin 1 proteins. Mice aged 6 months were treated for one month with nicotine injections, which led to an improvment in working and episodic memory compared to nontreated transgenic mice. This study investigated the effect of nicotine delivery on both young and old mice. For this purpose, 12 month old mice were treated with nicotine injections, and then tested for spatial memory. Like the young mice, they also displayed an improvement in spatial memory, demonstrating that nicotine enhances memory in both young and old mice. The amount of $A B$ was quantified, and following nicotine injections a reduction in $A \beta$, particularly in the oligomeric form, was found. This work confirmed the observation that AD 
mouse models display a reduction of $\alpha 7$ binding sites and PSD-95 puncta reflecting a synaptic deficit in this line. Both $\alpha 7$ binding sites and PSD-95 puncta were increased following nicotine treatment. The explanation proposed by the authors is that $\alpha 7 \mathrm{nAChR}$ activation through nicotine binding could promote survival pathways and recover the synaptic damage caused by $A ß$ (Inestrosa et al., 2013). Oddo et al. (2005) investigated the consequences of nAChR activation on tau pathology in AD model 3xTg-AD. This line was chosen because it showed cholinergic pathology with a decrease of $\alpha 7$ nAChRs in brain regions affected by $\mathrm{A} \beta$ deposition and tau aggregation. Chronic nicotine administration was performed in drinking water for 5 months. The long-term nicotine treatment caused faster tau aggregation in CA1 pyramidal neurons. The possible mechanism by which nicotine enhances the aggregation of tau is through the activation of p38-MAP kinase. This kinase is sensitive to $\mathrm{Ca}^{++}$, whose levels are increased following nAChR activation (Oddo et al., 2005). Even though nicotine showed a positive effect reducing plaque load (Hellström-Lindahl et al., 2004; Inestrosa et al., 2013; Nordberg et al., 2002), its use in AD treatment should be limited due to its toxic effect on tau pathology.

Shim et al. (2008) investigated the effect of nicotine administration in an AD mouse model harbouring the Swedish mutation. 12 month old mice were treated with three different doses of nicotine $(5 \mathrm{mg} / \mathrm{kg}, 30 \mathrm{mg} / \mathrm{kg}$ and $180 \mathrm{mg} / \mathrm{kg})$ in drinking water for 6 months. Nicotine treatment improved the memory deficit, highlighted with the Morris water maze task. Surprisingly, this study showed a dose dependent increase of $\alpha 7 \mathrm{nAChR}$, a result that is in contrast with the literature (Oddo et al., 2005). In the group that received the higher dose of nicotine, the level of $\alpha 7 \mathrm{nAChR}$ was restored to the level found in wild-type animals (Shim et al., 2008). However, nicotine is addictive and has numerous side effects, for example on the cardiovascular system. The use of cotinine for the treatment of $\mathrm{AD}$ was also investigated. We already cited an in vitro study on the protective effect of cotinine against $A ß$ toxicity (Gao et 
al., 2014). In a mouse model of $\mathrm{AD}$, cotinine treatment decreased the plaque load and was able to activate the Akt pathway, that was shown to be neuroprotective (Echeverria et al., 2011). Cotinine is an $\alpha 7 \mathrm{nAChR}$ PAM (positive allosteric modulator). It was already demonstrated that this molecule does not display side effects when administrated in humans (Hatsukami et al., 1997). Thus, cotinine is an interesting molecule for AD treatment (for a review see Echeverria and Zeitlin, 2012).

The neuroprotective effect of $4 \mathrm{OH}-\mathrm{GTS}-21$, an $\alpha 7 \mathrm{nAChR}$ agonist, was also investigated. The molecule was administered to PS1 and APP/PS1trangenic mice following a lesion to the fimbria fornix region (FFX). This novel model displayed deficits in spatial memory and reduced neuronal density. Whilst the spatial memory deficit was restored by 4OH-GTS-21 treatment, this molecule had no effect on neuronal density (Ren et al., 2007). Wild-type mice treated with nicotine or with SSR180711, another partial agonist of $\alpha 7$ (Biton et al., 2006), showed increased LTP, while the transgenic AD model APPSwe/PS1 $\Delta$ E9 showed no effect on LTP following SSR180711 treatment. The authors performed an autoradiographic study to investigate the number of $\alpha 7 \mathrm{nAChR}$ binding sites. Surprisingly, no decrease was found when transgenic and wild-type mice were compared, a result in contrast with work from other authors (Shim et al., 2008). The molecule SSR180711 seems to be effective in enhancing LTP in wild-type mice but is not able to interfere with $A ß-n A C h R$ binding, thus not being considered for AD treatment (Söderman et al., 2011).

Pregnenolone sulfate (PREGS) is an endogenous steroid known to ameliorate cognitive performance in animals. PREGS is a modulator of synaptic plasticity, acting on the activation of glutamatergic transmission (Smith et al., 2014). It was proposed that the positive action of PREGS is mediated by $\alpha 7 \mathrm{nAChR}$. In order to investigate this hypothesis, Yang et al. (2012) treated a mouse model obtained with injection of $A \beta_{25-35}$ for 7 days whit PREGS. The treatment improved spatial memory and reduced apoptosis in CA1 pyramidal cells. Even 
though the protective effect of PREGS is evident, less clear is whether or not it implies $\alpha 7$ nAChR activation (Yang et al., 2012).

Simvastatin (SV) is a statin commonly used in the clinic to control cholesterol levels and it was shown to improve cognitive function in AD patients (Simons et al., 2002; Sparks et al., 2006). In a study conducted by Zhi et al. (2014), this molecule was used to treat a mouse model obtained with injections of the peptide $A \beta_{25-35}$. Administration for 11 days of $\mathrm{SV}$ improved memory performance in the Morris water maze task and promoted survival of CA1 pyramidal cells. This effect was proposed to be promoted by $\alpha 7 \mathrm{nAChRs,} \mathrm{since} \mathrm{it} \mathrm{is} \mathrm{blocked}$ by MLA administration (Zhi et al., 2014).

A caveat with these pharmacological studies directed at $\alpha 7 \mathrm{nAChRs}$ is the contribution of potential off-target effects, hence other approaches have been investigated. The intracellular signaling initiated by the binding of $A B$ to $n A C h R$ at the cell surface requires the recruitment of Filamin A (FLNA), a scaffold protein that is known to crosslink actin, and in addition could also have a function in certain intracellular pathways (Stossel et al., 2001). Wang et al. showed that the association between FLNA and the $\alpha 7$ subunit is elevated in AD samples compared to age matched controls. A novel molecule called PTI-125 was used to interfere with the interaction of FLNA and $\alpha 7$. The treatment with PTI-125 prevents FLNA binding to $\alpha 7$ and as consequence reduces the affinity of $A \beta$ for $n A C h R s$, attenuating the toxic effect of Aß (Wang et al., 2012).

\section{Conclusion}

In this review we present evidence supporting the existence of a direct interaction between nAChRs and $A ß$. The effect of $A ß$ on $n A C h R$ physiology is complex. It was indeed shown that this interaction can lead to either activation of survival pathways or to a toxic effect. Under different experimental conditions, $A ß$ can act like an agonist or an antagonist on 
AChRs, which underlies the observed variability. Thus, nAChR activation, for example with nicotine, can have a protective effect against $A B$ exerted toxicity, with the clearance of the peptide. However, this interaction should be studied further to understand the cellular mechanism(s) underlying the activation of survival pathways and $A ß$ clearance, observed following nicotine administration. Moreover, the use of different $\alpha 7$ agonists to target this nAChR subtype is a promising approach that can be translated into AD therapy. Despite the fact that mainly the $\alpha 7$ subunit was investigated in the AD field, some data demonstrating the functional interaction between $A \beta$ and non- $\alpha$ nAChRs also exist. We believe that other nAChR subunits could be a target of $A B$ toxicity and their contribution to $A D$ pathology should be elucidated.

Agonist molecules are responsible for the activation of the receptor at the surface of the cell, and scaffold proteins anchoring nicotinic receptors mediate and regulate the transduction of the intracellular signal. These proteins that interact with the receptors, or directly linked interacting proteins, are largely unknown. In addition to nAChRs, these proteins also present future targets for the study of neurodegeneration research and potential treatment.

Finally, the possibility to generate multiple transgenic models expressing fAD associated mutations and KOs for nAChR subunits was explored. This approach showed apparently contrasting results that however could reflect a different role (protective or not) of the nicotinic receptors depending on $\mathrm{A} \beta$ concentration.

Significant evidence suggesting a potential role of nAChRs as therapeutic target in AD exists. These studies provide support for pursuing the investigations to define the detailed mechanism of nAChR neuroprotection and design $\mathrm{nAChR}$ agonists, antagonists or allosteric modulators for clinical translation. 


\section{Acknowledgments}

SL was supported by EU FP7 "BRAINTRAIN", Fondation pour la Recherche Médicale FRM and Institut Pasteur programme "PasteurInnov" 2012. 


\section{References}

Albuquerque, E.X., Pereira, E.F.R., Alkondon, M., and Rogers, S.W. (2009). Mammalian Nicotinic Acetylcholine Receptors: From Structure to Function. Physiol. Rev. 89, 73-120.

Arora, K., Alfulaij, N., Higa, J.K., Panee, J., and Nichols, R.A. (2013). Impact of Sustained Exposure to $\beta$-Amyloid on Calcium Homeostasis and Neuronal Integrity in Model Nerve Cell System Expressing $\alpha 4 \beta 2$ Nicotinic Acetylcholine Receptors. J. Biol. Chem. 288, 1117511190.

Auld, D.S., Kornecook, T.J., Bastianetto, S., and Quirion, R. (2002). Alzheimer's disease and the basal forebrain cholinergic system: relations to $\beta$-amyloid peptides, cognition, and treatment strategies. Prog. Neurobiol. 68, 209-245.

Bartus, R.T., Dean, R.L., Beer, B., and Lippa, A.S. (1982). The cholinergic hypothesis of geriatric memory dysfunction. Science $217,408-414$.

Berg, D.K., and Conroy, W.G. (2002). Nicotinic $\alpha 7$ receptors: Synaptic options and downstream signaling in neurons. J. Neurobiol. 53, 512-523.

Bigl, V., Woolf, N.J., and Butcher, L.L. (1982). Cholinergic projections from the basal forebrain to frontal, parietal, temporal, occipital, and cingulate cortices: A combined fluorescent tracer and acetylcholinesterase analysis. Brain Res. Bull. 8, 727-749.

Biton, B., Bergis, O.E., Galli, F., Nedelec, A., Lochead, A.W., Jegham, S., Godet, D., Lanneau, C., Santamaria, R., Chesney, F., et al. (2006). SSR180711, a Novel Selective $\alpha 7$ Nicotinic Receptor Partial Agonist: (1) Binding and Functional Profile. Neuropsychopharmacology 32, 1-16.

Bowen, D.M., Smith, C.B., White, P., and Davison, A.N. (1976). Neurotransmitter-related enzymes and indices of hypoxia in senile dementia and other abiotrophies. Brain J. Neurol. 99, 459-496.

Braak, H., and Braak, E. (1991). Neuropathological stageing of Alzheimer-related changes. Acta Neuropathol. (Berl.) 82, 239-259.

Changeux, J.-P., and Edelstein, S.J. (1998). Allosteric Receptors after 30 Years. Neuron 21, 959-980.

Contestabile, A. (2011). The history of the cholinergic hypothesis. Behav. Brain Res. 221, 334-340.

Coyle, J.T., Price, D.L., and DeLong, M.R. (1983). Alzheimer's disease: a disorder of cortical cholinergic innervation. Science 219, 1184-1190.

Dani, J.A., and Bertrand, D. (2007). Nicotinic Acetylcholine Receptors and Nicotinic Cholinergic Mechanisms of the Central Nervous System. Annu. Rev. Pharmacol. Toxicol. 47, 699-729.

Davies, P., and Maloney, A.J. (1976). Selective loss of central cholinergic neurons in Alzheimer's disease. Lancet 2, 1403. 
Dineley, K.T., Westerman, M., Bui, D., Bell, K., Ashe, K.H., and Sweatt, J.D. (2001). $\beta$ Amyloid Activates the Mitogen-Activated Protein Kinase Cascade via Hippocampal $\alpha 7$ Nicotinic Acetylcholine Receptors:In Vitro and In Vivo Mechanisms Related to Alzheimer's Disease. J. Neurosci. 21, 4125-4133.

Dineley, K.T., Bell, K.A., Bui, D., and Sweatt, J.D. (2002). $\beta$-Amyloid Peptide Activates $\alpha 7$ Nicotinic Acetylcholine Receptors Expressed in Xenopus Oocytes. J. Biol. Chem. 277, 25056-25061.

Dougherty, J.J., Wu, J., and Nichols, R.A. (2003). $\beta$-Amyloid Regulation of Presynaptic Nicotinic Receptors in Rat Hippocampus and Neocortex. J. Neurosci. 23, 6740-6747.

Dziewczapolski, G., Glogowski, C.M., Masliah, E., and Heinemann, S.F. (2009). Deletion of the $\alpha 7$ Nicotinic Acetylcholine Receptor Gene Improves Cognitive Deficits and Synaptic Pathology in a Mouse Model of Alzheimer's Disease. J. Neurosci. 29, 8805-8815.

Echeverria, V., and Zeitlin, R. (2012). Cotinine: A Potential New Therapeutic Agent against Alzheimer's disease. CNS Neurosci. Ther. 18, 517-523.

Echeverria, V., Zeitlin, R., Burgess, S., Patel, S., Barman, A., Thakur, G., Mamcarz, M., Wang, L., Sattelle, D.B., Kirschner, D.A., et al. (2011). Cotinine reduces amyloid- $\beta$ aggregation and improves memory in Alzheimer's disease mice. J. Alzheimers Dis. 24, 817835.

Games, D., Adams, D., Alessandrini, R., Barbour, R., Borthelette, P., Blackwell, C., Carr, T., Clemens, J., Donaldson, T., Gillespie, F., et al. (1995). Alzheimer-type neuropathology in transgenic mice overexpressing V717F $\beta$-amyloid precursor protein. Nature 373, 523-527.

Gao, J., Adam, B.-L., and Terry Jr., A.V. (2014). Evaluation of nicotine and cotinine analogs as potential neuroprotective agents for Alzheimer's disease. Bioorg. Med. Chem. Lett. 24, $1472-1478$.

Ghoneim, M.M., and Mewaldt, S.P. (1977). Studies on human memory: the interactions of diazepam, scopolamine, and physostigmine. Psychopharmacology (Berl.) 52, 1-6.

Giniatullin, R., Nistri, A., and Yakel, J.L. (2005). Desensitization of nicotinic ACh receptors: shaping cholinergic signaling. Trends Neurosci. 28, 371-378.

Gotti, C., and Clementi, F. (2004). Neuronal nicotinic receptors: from structure to pathology. Prog. Neurobiol. 74, 363-396.

Gotti, C., Moretti, M., Bohr, I., Ziabreva, I., Vailati, S., Longhi, R., Riganti, L., Gaimarri, A., McKeith, I.G., Perry, R.H., et al. (2006a). Selective nicotinic acetylcholine receptor subunit deficits identified in Alzheimer's disease, Parkinson's disease and dementia with Lewy bodies by immunoprecipitation. Neurobiol. Dis. 23, 481-489.

Gotti, C., Zoli, M., and Clementi, F. (2006b). Brain nicotinic acetylcholine receptors: native subtypes and their relevance. Trends Pharmacol. Sci. 27, 482-491.

Gotti, C., Moretti, M., Gaimarri, A., Zanardi, A., Clementi, F., and Zoli, M. (2007). Heterogeneity and complexity of native brain nicotinic receptors. Biochem. Pharmacol. 74, $1102-1111$. 
Gotti, C., Clementi, F., Fornari, A., Gaimarri, A., Guiducci, S., Manfredi, I., Moretti, M., Pedrazzi, P., Pucci, L., and Zoli, M. (2009). Structural and functional diversity of native brain neuronal nicotinic receptors. Biochem. Pharmacol. 78, 703-711.

Guillem, K., Bloem, B., Poorthuis, R.B., Loos, M., Smit, A.B., Maskos, U., Spijker, S., and Mansvelder, H.D. (2011). Nicotinic acetylcholine receptor $\beta 2$ subunits in the medial prefrontal cortex control attention. Science 333, 888-891.

Hatsukami, D.K., Grillo, M., Pentel, P.R., Oncken, C., and Bliss, R. (1997). Safety of cotinine in humans: physiologic, subjective, and cognitive effects. Pharmacol. Biochem. Behav. 57, $643-650$.

Hellström-Lindahl, E., Court, J., Keverne, J., Svedberg, M., Lee, M., Marutle, A., Thomas, A., Perry, E., Bednar, I., and Nordberg, A. (2004). Nicotine reduces A $\beta$ in the brain and cerebral vessels of APPsw mice. Eur. J. Neurosci. 19, 2703-2710.

Hernandez, C.M., Kayed, R., Zheng, H., Sweatt, J.D., and Dineley, K.T. (2010). Loss of $\alpha 7$ Nicotinic Receptors Enhances $\beta$-Amyloid Oligomer Accumulation, Exacerbating Early-Stage Cognitive Decline and Septohippocampal Pathology in a Mouse Model of Alzheimer's Disease. J. Neurosci. 30, 2442-2453.

Hsia, A.Y., Masliah, E., McConlogue, L., Yu, G.-Q., Tatsuno, G., Hu, K., Kholodenko, D., Malenka, R.C., Nicoll, R.A., and Mucke, L. (1999). Plaque-independent disruption of neural circuits in Alzheimer's disease mouse models. Proc. Natl. Acad. Sci. 96, 3228-3233.

Hsiao, K., Chapman, P., Nilsen, S., Eckman, C., Harigaya, Y., Younkin, S., Yang, F., and Cole, G. (1996). Correlative memory deficits, Abeta elevation, and amyloid plaques in transgenic mice. Science 274, 99-102.

Inestrosa, N.C., Godoy, J.A., Vargas, J.Y., Arrazola, M.S., Rios, J.A., Carvajal, F.J., Serrano, F.G., and Farias, G.G. (2013). Nicotine Prevents Synaptic Impairment Induced by Amyloid- $\beta$ Oligomers Through $\alpha 7$-Nicotinic Acetylcholine Receptor Activation. NeuroMolecular Med. $15,549-569$.

Khiroug, S.S., Harkness, P.C., Lamb, P.W., Sudweeks, S.N., Khiroug, L., Millar, N.S., and Yakel, J.L. (2002). Rat nicotinic ACh receptor 7 and 2 subunits co-assemble to form functional heteromeric nicotinic receptor channels. J. Physiol. 540, 425-434.

Kihara, T., Shimohama, S., Sawada, H., Honda, K., Nakamizo, T., Shibasaki, H., Kume, T., and Akaike, A. (2001). $\alpha 7$ Nicotinic Receptor Transduces Signals to Phosphatidylinositol 3Kinase to Block A $\beta$-Amyloid-induced Neurotoxicity. J. Biol. Chem. 276, 13541-13546.

Kim, H.-J., Moon, W.-J., and Han, S.-H. (2013). Differential Cholinergic Pathway Involvement in Alzheimer's Disease and Subcortical Ischemic Vascular Dementia. J. Alzheimers Dis. 35, 129-136.

Lamb, P.W., Melton, M.A., and Yakel, J.L. (2005). Inhibition of neuronal nicotinic acetylcholine receptor channels expressed in Xenopus oocytes by beta-amyloid1-42 peptide. J. Mol. Neurosci. 27, 13-21.

Lilja, A.M., Porras, O., Storelli, E., Nordberg, A., and Marutle, A. (2011). Functional Interactions of Fibrillar and Oligomeric Amyloid- $\beta$ with Alpha7 Nicotinic Receptors in 
Alzheimer's Disease. J. Alzheimers Dis. 23, 335-347.

Liu, Q., Kawai, H., and Berg, D.K. (2001). $\beta$-Amyloid peptide blocks the response of $\alpha 7$ containing nicotinic receptors on hippocampal neurons. Proc. Natl. Acad. Sci. 98, 4734-4739.

Liu, Q., Huang, Y., Xue, F., Simard, A., DeChon, J., Li, G., Zhang, J., Lucero, L., Wang, M., Sierks, M., et al. (2009). A Novel Nicotinic Acetylcholine Receptor Subtype in Basal Forebrain Cholinergic Neurons with High Sensitivity to Amyloid Peptides. J. Neurosci. 29, 918-929.

Liu, Q., Huang, Y., Shen, J., Steffensen, S., and Wu, J. (2012). Functional alpha7beta2 nicotinic acetylcholine receptors expressed in hippocampal interneurons exhibit high sensitivity to pathological level of amyloid ß peptides. BMC Neurosci. 13, 155-166.

Lozada, A.F., Wang, X., Gounko, N.V., Massey, K.A., Duan, J., Liu, Z., and Berg, D.K. (2012). Glutamatergic Synapse Formation is Promoted by $\alpha 7$-Containing Nicotinic Acetylcholine Receptors. J. Neurosci. 32, 7651-7661.

Martin, S.E., de Fiebre, N.E.C., and de Fiebre, C.M. (2004). The $\alpha 7$ nicotinic acetylcholine receptor-selective antagonist, methyllycaconitine, partially protects against $\beta$-amyloid1-42 toxicity in primary neuron-enriched cultures. Brain Res. 1022, 254-256.

Masliah, E., Mallory, M., Alford, M., DeTeresa, R., Hansen, L.A., McKeel, D.W.J., and Morris, J.C. (2001). Altered expression of synaptic proteins occurs early during progression of Alzheimer's disease. Neurol. 56, 127-129.

Messi, M.., Renganathan, M., Grigorenko, E., and Delbono, O. (1997). Activation of $\alpha 7$ nicotinic acetylcholine receptor promotes survival of spinal cord motoneurons. FEBS Lett. $411,32-38$.

Mesulam, M.M., Mufson, E.J., Levey, A.I., and Wainer, B.H. (1983). Cholinergic innervation of cortex by the basal forebrain: cytochemistry and cortical connections of the septal area, diagonal band nuclei, nucleus basalis (substantia innominata), and hypothalamus in the rhesus monkey. J. Comp. Neurol. 214, 170-197.

Moretti, M., Zoli, M., George, A.A., Lukas, R.J., Pistillo, F., Maskos, U., Whiteaker, P., and Gotti, C. (2014). The novel $\alpha 7 \beta 2$-nicotinic acetylcholine receptor subtype is expressed in mouse and human basal forebrain: biochemical and pharmacological characterization. Mol. Pharmacol. 86, 306-317.

Morley, B.J., and Happe, H.K. (2000). Cholinergic receptors: dual roles in transduction and plasticity. Hear. Res. 147, 104-112.

Mucke, L., Masliah, E., Yu, G.-Q., Mallory, M., Rockenstein, E.M., Tatsuno, G., Hu, K., Kholodenko, D., Johnson-Wood, K., and McConlogue, L. (2000). High-Level Neuronal Expression of A $\beta 1-42$ in Wild-Type Human Amyloid Protein Precursor Transgenic Mice: Synaptotoxicity without Plaque Formation. J. Neurosci. 20, 4050-4058.

Muir, J.L., Page, K.J., Sirinathsinghji, D.J., Robbins, T.W., and Everitt, B.J. (1993). Excitotoxic lesions of basal forebrain cholinergic neurons: effects on learning, memory and attention. Behav. Brain Res. 57, 123-131. 
Murray, T.A., Bertrand, D., Papke, R.L., George, A.A., Pantoja, R., Srinivasan, R., Liu, Q., Wu, J., Whiteaker, P., Lester, H.A., et al. (2012). $\alpha 7 \beta 2$ Nicotinic Acetylcholine Receptors Assemble, Function, and Are Activated Primarily via Their $\alpha 7-\alpha 7$ Interfaces. Mol. Pharmacol. $81,175-188$.

Nordberg, A., Hellström-Lindahl, E., Lee, M., Johnson, M., Mousavi, M., Hall, R., Perry, E., Bednar, I., and Court, J. (2002). Chronic nicotine treatment reduces $\beta$-amyloidosis in the brain of a mouse model of Alzheimer's disease (APPsw). J. Neurochem. 81, 655-658.

Le Novère, N.L., and Changeux, J.-P. (1995). Molecular evolution of the nicotinic acetylcholine receptor: An example of multigene family in excitable cells. J. Mol. Evol. 40, $155-172$.

Oddo, S., Caccamo, A., Green, K.N., Liang, K., Tran, L., Chen, Y., Leslie, F.M., and LaFerla, F.M. (2005). Chronic nicotine administration exacerbates tau pathology in a transgenic model of Alzheimer's disease. Proc. Natl. Acad. Sci. U. S. A. 102, 3046-3051.

Olivero, G., Grilli, M., Chen, J., Preda, S., Mura, E., Govoni, S., and Marchi, M. (2014). Effects of soluble $\beta$-amyloid on the release of neurotransmitters from rat brain synaptosomes. Front. Aging Neurosci. 6, 166.

Orr-Urtreger, A., Göldner, F.M., Saeki, M., Lorenzo, I., Goldberg, L., Biasi, M.D., Dani, J.A., Patrick, J.W., and Beaudet, A.L. (1997). Mice Deficient in the $\alpha 7$ Neuronal Nicotinic Acetylcholine Receptor Lack $\alpha$-Bungarotoxin Binding Sites and Hippocampal Fast Nicotinic Currents. J. Neurosci. 17, 9165-9171.

Pandya, A., and Yakel, J.L. (2011). Allosteric Modulator Desformylflustrabromine Relieves the Inhibition of $\alpha 2 \beta 2$ and $\alpha 4 \beta 2$ Nicotinic Acetylcholine Receptors by $\beta$-Amyloid1-42 Peptide. J. Mol. Neurosci. 45, 42-47.

Parri, H.R., Hernandez, C.M., and Dineley, K.T. (2011). Research update: Alpha7 nicotinic acetylcholine receptor mechanisms in Alzheimer's disease. Biochem. Pharmacol. 82, 931942.

Paterson, D., and Nordberg, A. (2000). Neuronal nicotinic receptors in the human brain. Prog. Neurobiol. 61, 75-111.

Perry, E.K., Tomlinson, B.E., Blessed, G., Bergmann, K., Gibson, P.H., and Perry, R.H. (1978). Correlation of cholinergic abnormalities with senile plaques and mental test scores in senile dementia. Br. Med. J. 2, 1457-1459.

Perry, E.K., Blessed, G., Tomlinson, B.E., Perry, R.H., Crow, T.J., Cross, A.J., Dockray, G.J., Dimaline, R., and Arregui, A. (1981). Neurochemical activities in human temporal lobe related to aging and Alzheimer-type changes. Neurobiol. Aging 2, 251-256.

Perry, E.K., Curtis, M., Dick, D.J., Candy, J.M., Atack, J.R., Bloxham, C.A., Blessed, G., Fairbairn, A., Tomlinson, B.E., and Perry, R.H. (1985). Cholinergic correlates of cognitive impairment in Parkinson's disease: comparisons with Alzheimer's disease. J. Neurol. Neurosurg. Psychiatry 48, 413-421.

Perry, E.K., Perry, R.H., Smith, C.J., Dick, D.J., Candy, J.M., Edwardson, J.A., Fairbairn, A., and Blessed, G. (1987). Nicotinic receptor abnormalities in Alzheimer's and Parkinson's 
diseases. J. Neurol. Neurosurg. Psychiatry 50, 806-809.

Perry, G., Lipphardt, S., Mulvihill, P., Kancherla, M., Mijares, M., Gambetti, P., Sharma, S., Maggiora, L., Cornette, J., and Lobl, T. (1988). Amyloid precursor protein in senile plaques of Alzheimer disease. Lancet 2, 746.

Petersen, R.C. (1977). Scopolamine induced learning failures in man. Psychopharmacology (Berl.) 52, 283-289.

Pettit, D.L., Shao, Z., and Yakel, J.L. (2001). $\beta$-Amyloid1-42 Peptide Directly Modulates Nicotinic Receptors in the Rat Hippocampal Slice. J. Neurosci. 21, RC120-RC120.

Plant, L.D., Boyle, J.P., Smith, I.F., Peers, C., and Pearson, H.A. (2003). The Production of Amyloid $\beta$ Peptide Is a Critical Requirement for the Viability of Central Neurons. J. Neurosci. 23, 5531-5535.

Puzzo, D., Privitera, L., Leznik, E., Fà, M., Staniszewski, A., Palmeri, A., and Arancio, O. (2008). Picomolar Amyloid- $\beta$ Positively Modulates Synaptic Plasticity and Memory in Hippocampus. J. Neurosci. 28, 14537-14545.

Pym, L., Kemp, M., Raymond-Delpech, V., Buckingham, S., Boyd, C. a R., and Sattelle, D. (2005). Subtype-specific actions of $\beta$-amyloid peptides on recombinant human neuronal nicotinic acetylcholine receptors $(\alpha 7, \alpha 4 \beta 2, \alpha 3 \beta 4)$ expressed in Xenopus laevis oocytes. Br. J. Pharmacol. 146, 964-971.

Quick, M.W., and Lester, R.A.J. (2002). Desensitization of neuronal nicotinic receptors. J. Neurobiol. 53, 457-478.

Ren, K., King, M.A., Liu, J., Siemann, J., Altman, M., Meyers, C., Hughes, J.A., and Meyer, E.M. (2007). The $\alpha 7$ nicotinic receptor agonist 4OH-GTS-21 protects axotomized septohippocampal cholinergic neurons in wild type but not amyloid-overexpressing transgenic mice. Neuroscience 148, 230-237.

Sarter, M., and Bruno, J.P. (1997). Cognitive functions of cortical acetylcholine: toward a unifying hypothesis. Brain Res. Rev. 23, 28-46.

Sarter, M., and Paolone, G. (2011). Deficits in Attentional Control: Cholinergic Mechanisms and Circuitry-Based Treatment Approaches. Behav. Neurosci. 125, 825-835.

Selkoe, D.J. (1991). The molecular pathology of Alzheimer's disease. Neuron 6, 487-498.

Selkoe, D.J. (2011). Alzheimer's disease. Cold Spring Harb. Perspect. Biol. 3.

Shim, S.B., Lee, S.H., Chae, K.R., Kim, C.K., Hwang, D.Y., Kim, B.G., Jee, S.W., Lee, S.H., Sin, J.S., Bae, C.J., et al. (2008). Nicotine Leads to Improvements in Behavioral Impairment and an Increase in the Nicotine Acetylcholine Receptor in Transgenic Mice. Neurochem. Res. $33,1783-1788$.

Shimohama, S., Taniguchi, T., Fujiwara, M., and Kameyama, M. (1986). Changes in Nicotinic and Muscarinic Cholinergic Receptors in Alzheimer-Type Dementia. J. Neurochem. 46, 288-293. 
Simons, M., Schwärzler, F., Lütjohann, D., Von Bergmann, K., Beyreuther, K., Dichgans, J., Wormstall, H., Hartmann, T., and Schulz, J.B. (2002). Treatment with simvastatin in normocholesterolemic patients with Alzheimer's disease: A 26-week randomized, placebocontrolled, double-blind trial. Ann. Neurol. 52, 346-350.

Smith, C.C., Gibbs, T.T., and Farb, D.H. (2014). Pregnenolone sulfate as a modulator of synaptic plasticity. Psychopharmacology (Berl.) 231, 3537-3556.

Søderman, A., Thomsen, M.S., Hansen, H.H., Nielsen, E.Ø., Jensen, M.S., West, M.J., and Mikkelsen, J.D. (2008). The nicotinic $\alpha 7$ acetylcholine receptor agonist ssr180711 is unable to activate limbic neurons in mice overexpressing human amyloid- $\beta 1-42$. Brain Res. 1227, $240-247$.

Söderman, A., Mikkelsen, J.D., West, M.J., Christensen, D.Z., and Jensen, M.S. (2011). Activation of nicotinic $\alpha 7$ acetylcholine receptor enhances long term potentation in wild type mice but not in APPswe/PS1 $\Delta$ E9 mice. Neurosci. Lett. 487, 325-329.

Sparks, D.L., Sabbagh, M., Connor, D., Soares, H., Lopez, J., Stankovic, G., Johnson-Traver, S., Ziolkowski, C., and Browne, P. (2006). Statin therapy in Alzheimer's disease. Acta Neurol. Scand. 114, 78-86.

Spires-Jones, T.L., and Hyman, B.T. (2014). The Intersection of Amyloid Beta and Tau at Synapses in Alzheimer's Disease. Neuron 82, 756-771.

Stossel, T.P., Condeelis, J., Cooley, L., Hartwig, J.H., Noegel, A., Schleicher, M., and Shapiro, S.S. (2001). Filamins as integrators of cell mechanics and signalling. Nat. Rev. Mol. Cell Biol. 2, 138-145.

Sudweeks, S.N., and Yakel, J.L. (2000). Functional and molecular characterization of neuronal nicotinic ACh receptors in rat CA1 hippocampal neurons. J. Physiol. 527, 515-528.

Tozaki, H., Matsumoto, A., Kanno, T., Nagai, K., Nagata, T., Yamamoto, S., and Nishizaki, T. (2002). The inhibitory and facilitatory actions of amyloid- $\beta$ peptides on nicotinic ACh receptors and AMPA receptors. Biochem. Biophys. Res. Commun. 294, 42-45.

Walsh, D.M., and Selkoe, D.J. (2004). Oligomers on the brain: the emerging role of soluble protein aggregates in neurodegeneration. Protein Pept. Lett. 11, 213-228.

Wang, H.-Y., Lee, D.H.S., D’Andrea, M.R., Peterson, P.A., Shank, R.P., and Reitz, A.B. (2000a). $\beta$-Amyloid1-42 Binds to $\alpha 7$ Nicotinic Acetylcholine Receptor with High Affinity Implications For Alzheimer's Disease Pathology. J. Biol. Chem. 275, 5626-5632.

Wang, H.-Y., Lee, D.H.S., Davis, C.B., and Shank, R.P. (2000b). Amyloid Peptide A $\beta 1-42$ Binds Selectively and with Picomolar Affinity to $\alpha 7$ Nicotinic Acetylcholine Receptors. J. Neurochem. 75, 1155-1161.

Wang, H.-Y., Stucky, A., Liu, J., Shen, C., Trocme-Thibierge, C., and Morain, P. (2009). Dissociating $\beta$-Amyloid from $\alpha 7$ Nicotinic Acetylcholine Receptor by a Novel Therapeutic Agent, S 24795, Normalizes $\alpha 7$ Nicotinic Acetylcholine and NMDA Receptor Function in Alzheimer's Disease Brain. J. Neurosci. 29, 10961-10973.

Wang, H.-Y., Bakshi, K., Shen, C., Frankfurt, M., Trocmé-Thibierge, C., and Morain, P. 
(2010). S 24795 Limits $\beta$-Amyloid- $\alpha 7$ Nicotinic Receptor Interaction and Reduces Alzheimer's Disease-Like Pathologies. Biol. Psychiatry 67, 522-530.

Wang, H.-Y., Bakshi, K., Frankfurt, M., Stucky, A., Goberdhan, M., Shah, S.M., and Burns, L.H. (2012). Reducing Amyloid-Related Alzheimer's Disease Pathogenesis by a Small Molecule Targeting Filamin A. J. Neurosci. 32, 9773-9784.

Wenk, G.L. (1997). The Nucleus Basalis Magnocellularis Cholinergic System: One Hundred Years of Progress. Neurobiol. Learn. Mem. 67, 85-95.

Whitehouse, P.J., Price, D.L., Clark, A.W., Coyle, J.T., and DeLong, M.R. (1981). Alzheimer disease: Evidence for selective loss of cholinergic neurons in the nucleus basalis. Ann. Neurol. 10, 122-126.

Whitehouse, P.J., Price, D.L., Struble, R.G., Clark, A.W., Coyle, J.T., and Delon, M.R. (1982). Alzheimer's disease and senile dementia: loss of neurons in the basal forebrain. Science 215, 1237-1239.

Whitehouse, P.J., Martino, A.M., Antuono, P.G., Lowenstein, P.R., Coyle, J.T., Price, D.L., and Kellar, K.J. (1986). Nicotinic acetylcholine binding sites in Alzheimer's disease. Brain Res. 371, 146-151.

Wonnacott, S., Barik, J., Dickinson, J., and Jones, I.W. (2006). Nicotinic receptors modulate transmitter cross talk in the CNS: nicotinic modulation of transmitters. J. Mol. Neurosci. 30, $137-140$.

Woolf, N.J. (1998). A structural basis for memory storage in mammals. Prog. Neurobiol. 55, 59-77.

Wu, J., Kuo, Y.-P., George, A.A., Xu, L., Hu, J., and Lukas, R.J. (2004). $\beta$-Amyloid Directly Inhibits Human $\alpha 4 \beta 2-N i c o t i n i c$ Acetylcholine Receptors Heterologously Expressed in Human SH-EP1 Cells. J. Biol. Chem. 279, 37842-37851.

Yang, R., Chen, L., Wang, H., Xu, B., Tomimoto, H., and Chen, L. (2012). Anti-amnesic effect of neurosteroid PREGS in A $325-35$-injected mice through $\sigma 1$ receptor- and $\alpha 7 \mathrm{nAChR}$ mediated neuroprotection. Neuropharmacology 63, 1042-1050.

Young, J.W., Finlayson, K., Spratt, C., Marston, H.M., Crawford, N., Kelly, J.S., and Sharkey, J. (2004). Nicotine improves sustained attention in mice: evidence for involvement of the alpha7 nicotinic acetylcholine receptor. Neuropsychopharmacol. 29, 891-900.

Young, J.W., Crawford, N., Kelly, J.S., Kerr, L.E., Marston, H.M., Spratt, C., Finlayson, K., and Sharkey, J. (2007). Impaired attention is central to the cognitive deficits observed in alpha 7 deficient mice. Eur. Neuropsychopharmacol. 17, 145-155.

Zanardi, A., Ferrari, R., Leo, G., Maskos, U., Changeux, J.-P., and Zoli, M. (2007). Loss of high-affinity nicotinic receptors increases the vulnerability to excitotoxic lesion and decreases the positive effects of an enriched environment. FASEB J. 21, 4028-4037.

Zhi, W.-H., Zeng, Y.-Y., Lu, Z.-H., Qu, W.-J., Chen, W.-X., Chen, L., and Chen, L. (2014). Simvastatin Exerts Antiamnesic Effect in A $325-35$-Injected Mice. CNS Neurosci. Ther. 20, $218-226$. 
Zoli, M., Léna, C., Picciotto, M.R., and Changeux, J.P. (1998). Identification of four classes of brain nicotinic receptors using beta2 mutant mice. J. Neurosci. 18, 4461-4472.

Zoli, M., Picciotto, M.R., Ferrari, R., Cocchi, D., and Changeux, J.P. (1999). Increased neurodegeneration during ageing in mice lacking high-affinity nicotine receptors. EMBO J. $18,1235-1244$. 
Table 1

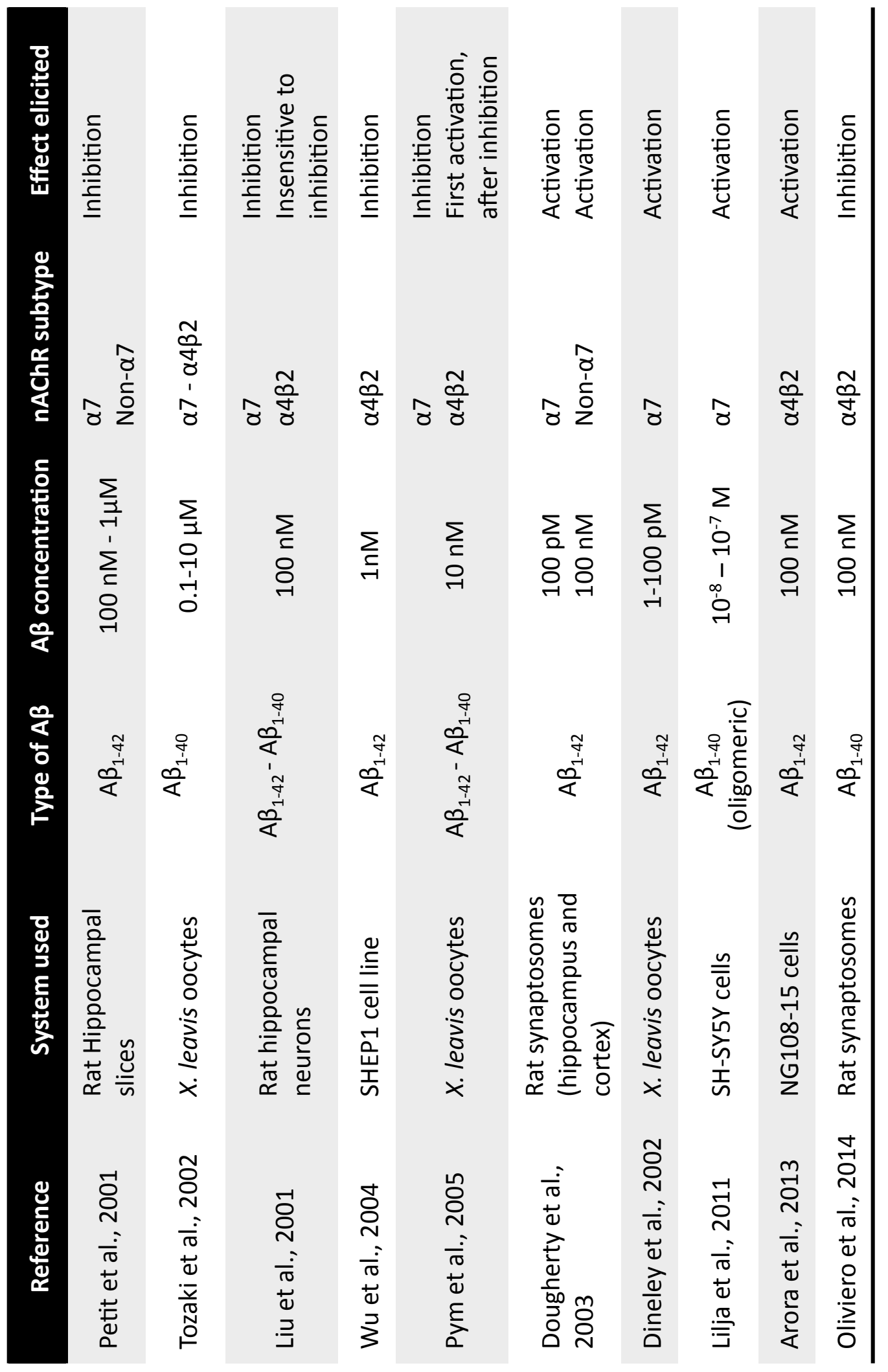


Table 2

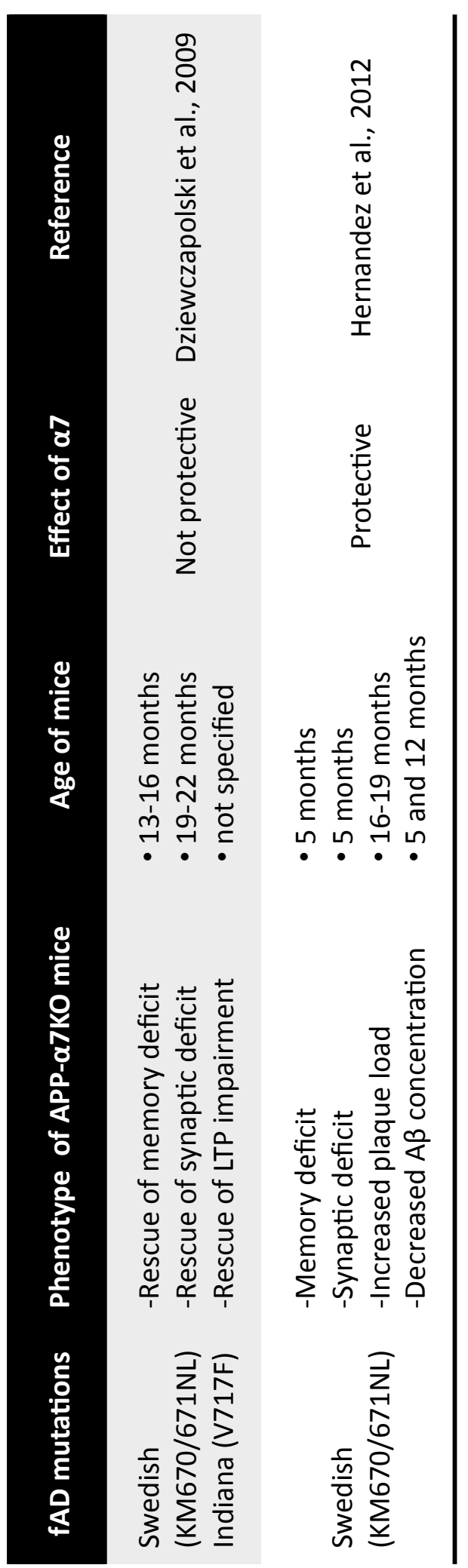




\section{Table Legends}

\section{Table 1}

Action of $A ß$ on nAChRs: The incubation with $A B$ activates or inhibits nAChRs. Here we summarised the results from the literature with particular attention on the $A ß$ fragment and concentrations used, the model in which the experiments were performed and the nAChR subtype investigated.

\section{Table 2}

Conflicting data on $\alpha 7 \mathrm{KO}$ crossed with $\mathrm{AD}$ model: Comparison of two published studies showing the AD model used for the generation of the APP- $\alpha 7 \mathrm{KO}$ line, the phenotype of the obtained APP- $\alpha 7 \mathrm{KO}$ with the age of tested mice and the overall effect of $\alpha 7 \mathrm{nAChRs}$. 